\title{
Manajemen Asuhan Keperawatan Psikososial Dengan Masalah Kecemasan Pada Penderita Hipertensi Di Subulussalam
}

\author{
Novia \\ noviakdr@gmail.com

\section{BAB 1} \\ PENDAHULUAN
}

\subsection{Latar Belakang}

Hipertensi atau tekanan darah tinggi merupakan suatu keadaan dimana terjadinya peningkatan tekanan darah yang tidak normal dalam pembuluh darah arteri dan terjadi secara terus menerus (Muriyati \& Yahya, 2018). Hipertensi merupakan salah satu Penyakit Tidak Menular (PTM) yang menjadi masalah kesehatan penting di seluruh dunia karena distribusinya yang tinggi dan terus meningkat.

Menurut World Health Organization (WHO) tahun 2016, satu milyar orang di dunia menderita hipertensi, dua pertiga diantaranya berada di Negara berkembang yang berpenghasilan rendah-sedang. Prevalensi hipertensi akan terus meningkat tajam, diprediksikan pada tahun 2025 nanti, sekitar 29\% orang dewasa di seluruh dunia menderita hipertensi. Hipertensi telah mengakibatkan kematian sekitar 8 juta orang setiap tahun, 1,5 juta kematian terjadi di Asia Tenggara, yang sepertiga populasinya menderita hipertensi (Kemenkes RI, 2013)..

Di Indonesia prevalensi kecemasan belum diketahui secara pasti, namun diprediksi sekitar 9-12\% populasi penduduk mengalami kecemasan. Hasil penelitian Apriansyah, Romadoni dan Andrianovita (2014) bahwa responden yang akan dilakukan tindakan operasi mengalami kecemasan kategori sedang dan berat berjumlah 23 responden (50\%) dari total 46 responden yang diteliti 
dan kecemasan ringan yang terjadi pada responden demngan keluhan nyeri berjumlah 10 responden $(21,7 \%)$ dari total 46 responden (Pardede et al., 2021).

Menurut data dari Riskesdas tahun 2017 menyatakan bahwa lansia yang mengalami kecemasan menyebabkan terjadinya peningkatan tekanan darah. Kecemasan adalah kekhawatiran yang tidak jelas dan menyebar yang berkaitan dengan perasaan tidak pasti dan tidak berdaya. Keadaan emosi ini tidak memiliki obyek yang spesifik. Gangguan kecemasan dan depresi di derita oleh 40 juta populasi orang dewasa di Amerika dan diprediksi 20\% dari populasi dunia menderita kecemasan (Kaplan \& Sadock, 2016).

Kecemasan adalah kekhawatiran yang tidak jelas dan menyebar, yang berkaitan dengan perasaan tidak pasti dan tidak berdaya. Keadaan emosi ini tidak memiliki objek yang spesifik. Kecemasan di alami secara subjektif dan dikomunikasikan secara interpersonal dapat menjadi suatu kekuatan motivasi untuk pertumbuhan dan perkembangan pada individu yang bersangkutan (Marbun, Pardede, 2019). Stres akan meningkatkan resistensi pembuluh darah perifer dan curah jantung sehingga akan menstimulasi aktivitas syaraf simpatik. Adapun stres ini dapat berhubungan dengan pekerjaan, kelas sosial, ekonomi, dan karakteristik personal (Setyaningsih, 2015). Salah satu cara yang dapat ditempuh penderita hipertensi adalah dengan menghindari stres dan cemas yang berlebihan serta beristirahat dengan cukup. Sebagai manusia terkadang tidak dapat terus menerus menjaga agar kondisi yang dianjurkan dokter dapat dipertahankan, sebab stres dan cemas sewaktu-waktu dapat menyerang penderita hipertensi (Zahara, 2017).

Kecemasan adalah ketegangan, rasa tidak aman dan kekawatiran yang timbul karena dirasakan terjadi sesuatu yang tidak menyenangkan tetapi sumbernya sebagian besar tidak diketahui dan berasal dari dalam (Wahyuni, 2018). Ansietas atau cemas sering dialami oleh hampir semua manusia yang sifatnya subjektif dan patologik (Abadiyah, 2020). Kecemasan yang terjadi tidak saja dialami oleh seorang pasien tetapi dapat juga dialami oleh perawat karena 
perawat terkadang cemas ketika berhadapan dengan pasien dan keluarga pasien (Pardede et al, 2020).

Hasil survey awal yang dilakukan di Subussalam pada tanggal 5 Oktober 2021 kepada Ny. G didapatkan bahwa pasien menderita Hipertensi dengan masalah psikososial kecemasan. Saat observasi diketahui pasien gelisah, lemas, sakit kepala, dan mengeluh badannya terasa lemas, kehilangan selera makan, dan saat dilakukan pengukuran tekanan darah Ny.G tinggi sehingga pasien tidak mampu melakukan aktivitas seperti biasanya.

\subsection{Rumusan Masalah}

Berdasarkan latar belakang masalah tersebut maka dapat dirumuskan masalah sebagai berikut : Bagaimana Memberikan Asuhan Keperawatan Jiwa Pada Ny.G dengan Hipertensi Pada Psikososial Kecemasan Di Subulussalam.

\subsection{Tujuan Penulisan}

Adapun tujuannya sebagai berikut :

\subsubsection{Tujuan Umum}

Untuk memberikan asuhan keperawatan pada Ny.G dengan masalah kecemasan

\subsubsection{Tujuan Khusus}

1. Mahasiswa mampu melakukan pengkajian pada Ny.G dengan masalah kecemasan

2. Mahasiswa mampu melakukan diagnosa pada Ny.G dengan masalah kecemasan

3. Mahasiswa mampu membuat intervensi pada Ny.G dengan masalah kecemasan

4. Mahasiswa mampu melakukan impelementasi pada Ny.G dengan masalah kecemasan

5. Mahasiswa mampu membuat evaluasi pada Ny.G dengan masalah kecemasan 


\section{BAB 2 \\ TINJAUAN TEORITIS}

\subsection{Konsep Hipertensi}

\subsubsection{Definisi Hipertensi}

Hipertensi atau tekanan darah tinggi adalah kondisi medis kronis di mana tekanan darah di arteri meningkat, yang mengharuskan jantung bekerja lebih keras dari biasanya untuk mengalirkan darah melalui pembuluh darah (Ibekwe, 2015). Hipertensi merupakan suatu keadaan tekanan darah dalam arteri mengalami peningkatan yang tidak normal secara terus menerus.

Kecemasan (anxiety) merupakan perasaan takut yang tidak jelas penyebabnya dan tidak didukung oleh situasi yang ada. Kecemasan dapat dirasakan oleh setiap orang jika mengalami tekanan dan perasaan mendalam yang menyebabkan masalah psikiatrik dan dapat berkembang dalam jangka waktu lama. Kecemasan adalah kekhawatiran yang tidak jelas dan menyebar, yang berkaitan dengan perasaan tidak pasti dan tidak berdaya. Keadaan emosi ini tidak memiliki objek yang spesifik. Kecemasan di alami secara subjektif dan dikomunikasikan secara interpersonal dapat menjadi suatu kekuatan motivasi untuk pertumbuhan dan perkembangan pada individu yang bersangkutan (Marbun, Pardede \& Perkasa, 2019) 
Hipertensi dapat mengakibatkan suplai oksigen dan nutrisi yang dibawa oleh darah terhambat sampai ke jaringan tubuh yang membutuhkan, sehingga memberi gejala berlanjut pada suatu target organ tubuh yang menimbulkan kerusakan lebih berat pada target organ bahkan kematian (Kayce \& Twiggs, 2018).

\subsubsection{Etiologi}

Hipertensi merupakan suatu penyakit dengan kondisi medis yang beragam. Bagi sebagian besar pasien dengan tekanan darah tinggi, penyebabnya tidak diketahui. Ini diklasifikasikan sebagai hipertensi primer atau esensial. Sebagian kecil pasien memiliki penyebab spesifik tekanan darah tinggi, yang diklasifikasikan sebagai hipertensi sekunder. Lebih dari $90 \%$ pasien dengan tekanan darah tinggi memiliki hipertensi primer. Hipertensi primer tidak dapat disembuhkan, tetapi dapat dikontrol dengan terapi yang tepat (termasuk modifikasi gaya hidup dan obat-obatan). Faktor genetik dapat memainkan peran penting dalam pengembangan hipertensi primer. Dimana bentuk tekanan darah tinggi ini cenderung berkembang secara bertahap selama bertahuntahun (Lestari, 2018).

Kurang dari $10 \%$ pasien dengan tekanan darah tinggi memiliki hipertensi sekunder. Hipertensi sekunder disebabkan oleh kondisi medis atau pengobatan yang mendasarinya. Mengontrol kondisi medis yang mendasarinya atau menghilangkan obat-obatan penyebab akan mengakibatkan penurunan tekanan darah sehingga menyelesaikan hipertensi sekunder. Bentuk tekanan darah tinggi ini cenderung muncul tiba-tiba dan sering menyebabkan tekanan darah lebih tinggi daripada hipertensi primer (Kayce \& Twiggs, 2018).

\subsubsection{Faktor Risiko}

a. Faktor risiko yang tidak dapat diubah

1. Etnis 
Menurut data dari Third National Health and Nutrition Examination Survey (NHANES III, 1988-1991) dalam Sheps (2005) menunjukkan bahwa jumlah penderita hipertensi berkulit hitam $40 \%$ akan lebih tinggi dibandingkan dengan yang berkulit putih. Hal ini belum diketahui secara pasti penyebabnya, namun dalam orang berkulit hitam ditemukan kadar rennin yang lebih rendah dan sensitifitas terhadap vasopresin lebih besar (Rustiana, 2014).

2. Riwayat Keluarga

Faktor genetik pada keluarga tertentu akan menyebabkan keluarga itu mempunyai risiko menderita hipertensi. Hal ini berhubungan dengan peningkatan kadar sodium intraseluler dan rendahnya rasio antara potasium terhadap sodium. Berbagai penelitian dan study kasus menguatkan bahwa faktor keturunan merupakan salah satu penyebab terjadinya hipertensi, dimana jika dalam keluarga ada yang menderita hipertensi 25-60\% akan terjadi pada anaknya (Lili \&Tantan, 2007).

3. Usia

Pasien yang berumur di atas 60 tahun mempunyai tekanan darah di atas 140/90 mmHg akan menyebabkan perubahan alami pada jantung, pembuluh darah dan hormone. Berdasarkan jurnal epidemiologi hubungan karakteristik dan obesitas sentral dengan kejadian hipertensi bahwa kelompok hipertensi sebanyak $(87,00 \%)$ berusia $>59$ tahun., sementara usia $\leq 59$ tahun hanya $(58,00 \%)$ yang hipertensi (Amanda and Martini, 2018).

4. Jenis kelamin. 
Hasil pengamatan Third National Health and Nutrition Examination Survey (NHANES) III memperlihatkan bahwa distribusi hipertensi lebih tinggi pada populasi laki-laki dibandingkan populasi perempuan pada kelompok sebelum menopause. Pada masa setalah menopause atau mendekati usia 60 tahun maka distribusi hipertensi kedua kelompok hampir sama. Hasil penelitian yang di lakukan oleh Hesti Rahayu (2012) menunjukkan bahwa kejadian hipertensi lebih tinggi terjadi pada perempuan sebesar 68,3\% dibandingkan laki-laki sebesar 31,7\% (Rustiana, 2014).

b. Faktor risiko yang dapat diubah

1. Merokok.

Kandungan dalam rokok terdapat nikotin yang dapat menyebabkan meningkatnya denyut jantung dan menyebabkan vasokonstriksi perifer yang akan meningkatkan tekanan darah arteri pada jangka waktu yang pendek, selama dan setelah merokok. Dengan menghentikan rokok, maka kemungkinan terjadinya hipertensi, serangan jantung, stroke, dan penyakit lainnya akan menurun (Rustiana, 2014).

2. Berat Badan Berlebih

Berat badan merupakan faktor determinan pada tekanan darah pada kebanyakan kelompok etnik disemua umur. Penurunan berat badan dianjurkan untuk mengurangi tekanan darah pada orang dewasa yang kelebihan berat badan atau obesitas. Direkomendasikan diet sehat jantung dan peningkatan aktivitas fisik melalui program olahraga terstruktur.

3. Konsumsi Natrium

World Health Organization (WHO) merekomendasikan pola konsumsi garam yang dapat mengurangi risiko terjadinya 
hipertensi yaitu tidak lebih dari $100 \mathrm{mmol}$ (sekitar 2,4 gram sodium atau 6 gram garam) perhari. Konsumsi natrium yang berlebih menyebabkan konsentrasi natrium di dalam cairan ekstraseluler meningkat sehingga volume darah meningkat, dan berdampak kepada timbulnya hipertensi (Nuraini, 2015). Asupan natrium harus dikurangi, dan kalium harus ditambah kecuali dikontra indikasikan.

4. Konsumsi Alkohol dan Kafein

Konsumsi secara berlebihan alkohol dan kafein yang terdapat dalam minuman kopi, teh dan cola akan meningkatkan risiko terjadinya hipertensi pada seseorang. Alkohol bersifat meningkatkan aktivitas saraf simpatis karena dapat merangsang sekresi corticotropin releasing hormone (CRH) yang berujung pada peningkatan tekanan darah. Sementara kafein dapat menstimulasi jantung untuk bekerja lebih cepat sehingga mengalirkan lebih banyak cairan pada setiap detiknya (Irza, 2009). Kafein juga merangsang kelenjar adrenal melepas lebih banyak kartisol dan adrenalin yang memicu tekanan darah meningkat (Rustiana, 2014).

5. Aktivitas Fisik

Aktivitas fisik teratur didefinisikan sebagai olahraga sedang yang berlangsung tidak kurang dari 30 menit, $\geq 3$ kali per minggu.Orang-orang yang tidak aktif cenderung mempunyai detak jantung lebih cepat dan otot jantung mereka harus bekerja lebih keras pada setiap kontraksi, semakin keras dan sering jantung harus memompa semakin besar pula kekuatan yang mendesak arteri (Nuraini, 2015). 
Aktivitas fisik yang mengangkat beban sebaiknya dihindari karena dapat meningkatkan tekanan darah secara mendadak sebagai respon vagal (Rustiana, 2014).

Contoh aktivitas fisik (olahraga) yang dapat dilakukan untuk menurunkan tekanan darah tinggi adalah jalan pagi,jalan kaki, sebam, bersepeda dan berenang. Kegiatan aktiviats ini disarankan agar dilakukan $\geq 30$ menit per hari dan $\geq 3$ hari per minggu (Kemenkes RI, 2015).

\subsubsection{Patofisiologi}

Mengenai patofisiologi hipertensi masih banyak terdapat ketidakpastian. Beberapa mekanisme fisiologis terlibat dalam mempertahankan tekanan darah yang normal, dan gangguan pada mekanisme ini dapat menyebabkan terjadinya hipertensi esensial. Faktor yang telah banyak diteliti ialah : asupan garam, obesitas, resistensi terhadap insulin, sistem renin-angiotensin dan sistem saraf simpatis (Lumbantobing, 2008).

Ada dua unsur utama yang menyebabkan kenaikan hipertensi yaitu cardiac output dan tahanan perifer total. Apabila peningkatan tekanan disebabkan oleh jalur yang pada akhirnya menyebabkan peningkatan cardiac output, maka hipertensi ini menyebabkan tekanan sistolik akan jauh lebih tinggi dibandingkan dengan diastolik. Apabila peningkatan tekanan itu disebabkan oleh kenaikan tahan perifer total maka hipertensi yang terjadi menyebabkan peningkatan tekana sistolik dan diastolik yang bersamaan, atau lebih sering tekanan diastolik meningkat lebih tinggi dibandingkan dengan tekanan sistolik. Kejadian hipertensi resisten dimana tekanan diastolik peningkatannya lebih besar disbanding dengan tekanan sistolik dapat terjadi jika peningkatan 
tahanan perifer total sudah memperlambat fungsi ejeksi daripada cardiac output (Kadir, 2015).

Keseimbangan curah jantung dan tahanan perifer dapat mempertahankan tekanan darah yang normal. Sebagian besar pasien dengan hipertensi esensial mempunyai curah jantung yang normal namun tahanan periferrnya meningkat. Tahanan perifer ditentukan bukan oleh arteri yang besar atau kapiler, melainkan oleh arteriola kecil, yang dindingnya mengandung sel otot polos. Kontraksi sel otot polos diduga berkaitan dengan peningkatan konsentrasi kalsium intraseluler. Kontraksi otot polos berlangsung lama diduga menginduksi perubahan struktural dengan penebalan dinding pembuluh darah arteriola, mungkin dimediasi oleh angiotensin, dan dapat mengakibatkan peningkatan tahanan perifer yang irreversible. Pada hiperetnsi yang sangat dini, tahanan perifer tidak mengikat dan peningkatan tekanan darah disebabkan oleh meningkatnya curah jantung, yang berkaitan dengan overaktivitas simpatis. Peningkatan tahanan perifer yang terjadi kemngkinan merupakan kompensasi untuk mencegah agar peningkatan tekanan tidak disebarluaskan ke jaringan pembuluh darah kapiler, yang akan dapat mengganggu homeostasis sel secara substansial (Lumbantobing, 2008).

Kemudian sistem renin-angiotensin mungkin merupakan sistem endokrin yang paling penting dalam mengontrol tekanan darah. Renin disekresi dari apparatus juxtaglomerular ginjal sebagai jawaban terhadap kurang perfusi glomerular atau kuarang asupan garam(Lumbantobing, 2008). Renin adalah enzim yang diproduksi oleh ginjal yang mengatalis substrat protein plasma untuk memisahkan angiotensin (Black J.M, 2009). Ia juga dilepas sebagai jawaban terhadap stimulasi dan sistem saraf simpatis. Renin bertanggung jawab mengkorversi substrat renin (angiotensinogen) menjadi angiotensin II di paru - paru oleh angiotensin converting enzim (ACE). Angiotensin 
II merupakan vasokontriktor yang kuat dan mengakibatkan peningkatan tekanan darah (Lumbantobing, 2008).

Kemudian angiotensin II ke angiotensin III, selain sebagai vasokonstriktor juga berperan untuk pelepasan aldosterone. Dengan meningkatnya aktivitas sistem saraf simpatik, angiotensin II dan III tampaknya juga menghambat ekskresi natrium, yang menghasilkan naiknya tekanan darah. Sekresi renin yang bertambah telah diteliti sebagai penyebab meningkatnya resistensi vascular pariferal pada hipertensi primer. Sel endotel vascular terbukti penting dalam hipertensi. Sel endotel memproduksi nitrat oksida yang mendilatasi atriole dan endothelium yang mengonstriksikannya. Disfungsi endothelium telah berimplikasi pada hipertensi esensial manusia (Black J.M, 2009).

Stimulasi sistem saraf otonom dapat menyebabkan konstriksi arteriola dan dilatasi arteriola. Jadi sistem saraf otonom mempunyai peranan yang penting dalam mempertahankan tekanan darah yang normal. Ia juga mempunyai peranan penting dalam memediasi perubahan yang berlangsung singkat pada tekanan darah sebagai jawaban terhadap stress dan kerja fisik (Lumbantobing, 2008). Baroreseptor dan kemoreseptor arteri bekerja secara reflex untuk mengontrol tekanan darah. Baroreseptor, reseptor peregangan utama, ditemukan di sinur karotis, aorta, dan dinsing bilik jantung kiri. Mereka memonitor tingkat tekanan arteri dan megatasi peningkatan melalui vasodilatasi dan memperlambat denyut jantung melalui saraf vagus. Kemoreseptor berada di medulla dan tubuh karotis aorta, sensitive terhadap perubahan dalam konsentrasi oksigen, karbondioksida, dan ion hydrogen $(\mathrm{pH})$ dalam darah. Penurunan konsentrasi oksigen arteria tau $\mathrm{pH}$ menyebabkan kenaikan refleksif pada tekanan, sementara kenaikan konsentrasi karbondioksida menyebabkan penurunan tekanan, darah. Perubahan - perubahan pada volume cairan memengaruhi tekanan 
arsetik sistemik. Dengan demikian kelainan dalam transport natrium dalam tubulus ginjal mungkin menyebabkan hipertensi esensial. Ketika kadar natrium dan air berlebih, volume total darah meningkat, dengan demikian meningkatkan tekanan darah. Perubahan - perubahan patologis yang mengubah ambang tekanan dimana ginjal mengekskresikan garam dan air mengubah tekanan darah sistemik. Selain itu, produkasi hormone perubahan natrium yang berlebihan menyebabkan hipertensi (Black J.M, 2009).

Peptide natrium natriuretic atau atrial natriuretic peptide/ANP merupakan hormone yang diproduksi oleh natrium jantung sebagai jawaban terhadap peningkatan volume darah. Efeknya ialah meningkatkan ekskresi garam dan air dari ginjal, jadi sebagai semacam diureting alamiah. Gangguan pada sistem ini dapat mengakibatkan retensi cairan dan hipertensi (Lumbantobing, 2008).

Hipertensi sekunder banyak disebabkan oleh kelainan - kelainan seperti masalah ginjal, vascular, neurologis, obat dan makanan yang secara langsung atau tidak langsung berpengaruh negatif terhadap ginjal dan dapat mengakibatkan gangguan serius pada organ - organ ini yang mengganggu ekskresi natrium, perfusi renal, atau mekanisme renin-angiotensin- aldosteron, yang mengakibatkan naiknya tekanan darah dari waktu ke waktu. Kelebihan aldosterone mengakibatkan renal menyimpan natrium dan air, memperbanyak volume darah, dan menaikkan tekanan darah. Permasalahan adrenokorsikal lainnya dpat mengakibatkan produksi kortisol yang berlebihan (sindrom cushing). (Black J.M, 2009).

\subsubsection{Patofisiologi}

Klasifikasi hipertensi dapat di bedakan berdasarkan penyebabnya dan berdasarkan derajat tekanan darah.

a. Berdasarkan Penyebabnya 
1. Hipertensi primer, Hipertensi primer atau esensial adalah jenis yang paling umum dari Hipertensi. Hipertensi yang penyebabnya tidak diketahui (idiopatik), hipertensi primer tidak dapat disembuhkan, tetapi dapat dikontrol dengan terapi yang tepat (termasuk modifikasi gaya hidup dan obat-obatan). Faktor genetik dapat memainkan peran penting dalam pengembangan hipertensi primer (Kayce Bell, June Twiggs, 2018).

2. Hipertensi sekunder, Hipertensi yang diketahui penyebabnya. Kurang dari $10 \%$ pasien dengan tekanan darah tinggi memiliki hipertensi sekunder. Hipertensi sekunder disebabkan oleh kondisi medis atau pengobatan yang mendasarinya, misalnya penyakit ginjal, tiroid, obat pil $\mathrm{KB}$, dekongestan dan lainnya (Kayce Bell, June Twiggs, 2018).

b. Berdasarkan Derajat Tekanan Darah

Tekanan darah bervariasi pada populasi dan cenderung untuk meningkat sesuai bertambahnya usia. Risiko terjadinya komplikasi vaskuler meningkat dengn progresif dan berbanding lurus dengan kenaikan tekanan darah sehingga menentukan tahapan dari hipertensi masih diperdebatkan.

\subsection{Konsep Kecemasan}

\subsubsection{Definisi Kecemasan}

Kecemasan merupakan suatu respon psikologis maupun fisiologis individu terhadap suatu keadaan yang tidak menyenangkan, atau reaksi atas situasi yang dianggap mengancam (Hulu \& Pardede, 2016). Kecemasan merupakan suatu keadaan perasaan gelisah, ketidaktentuan, ada rasa takut dari kenyataan atau persepsi ancaman sumber aktual yang tidak diketahui masalahnya (Pardede \& Simangunsong, 2020). Beberapa penelitian sudah dilakukan tentang kecemasan dan terapi 
yang diberikan untuk mengatasi kecemasan seperti penelitian (Marbun, et al , 2019; Pardede \& Simangunsong, 2020; Pardede, Sitepu \& Saragih; Pardede \& Tarigan, 2020).

Ansietas atau cemas sering dialami oleh hampir semua manusia yang sifatnya subjektif dan patologik (Abadiyah, 2020). Kecemasan yang terjadi tidak saja dialami oleh seorang pasien tetapi dapat juga dialami oleh perawat karena perawat terkadang cemas ketika berhadapan dengan pasien dan keluarga pasien (Pardede et al, 2020). Kecemasan adalah ketegangan, rasa tidak aman dan kekawatiran yang timbul karena dirasakan terjadi sesuatu yang tidak menyenangkan tetapi sumbernya sebagian besar tidak diketahui dan berasal dari dalam (Wahyuni, 2018).

Kecemasan atau sering dikenal khawatir adalah suatu pengalaman subjektif mengenai ketegangan mental yang menggelisahkan sebagai reaksi umum dan ketidakmampuan menghadapi masalah atau adanya rasa aman (Alicia, 2017). Kecemasan suatu kondisi perasaan yang berkaitan dengan ketakutan disertai gejala fisik seperti jantung berdebar nafas pendek atau nyeri dada, keringat dingin tangan geetaran yang dapat disebabkan oleh genetik, biokimia otak dan mekanisme fightfight. ( Febrianti, Hamid, \& Wardani, 2015) Kecemasan adalah perasaan was-was, khawatir,atau tidak nyaman seakan-akan akan terjadi sesuatu yang dirasakan sebagai ancaman Ansietas berbeda dengan rasa takut. Takut merupakan penilaian intelektual terhadap ssuatu yang berbahaya, sedangkan ansietas adalah respon emosional terhadap penilaian tersebut (Nurhalimah, 2016).

Kecemasan merupakan suatu perasaan subjektif mengenai ketegangan mental yang menggelisahkan sebagai reaksi umum dari ketidak mampuan mengatasi suatu masalah atau tidak adanya rasa aman. Perasaan yang tidak menentu tersebut pada umumnya tidak 
menyenangkan yang nantinya akan menimbulkan atau disertai perubahan fisiologis dan psikologis (Lestari, 2018).

Kecemasan mungkin hadir pada beberapa tingkat dalam kehidupan setiap individu, tetapi derajat dan frekuensi dengan yang memanifestasikan berbeda secara luas. Respon masing-masing individu memiliki kecemasan berbeda. Tepi emosional yang memprovokasi kecemasan untuk merangsang kreativitas atau kemampuan pemecahan masalah, yang lainnya dapat menjadi bergerak ke tingkat patologis. Perasaan umumnya dikategorikan menjadi empat tingkat untuk tujuan pengobatan : ringan, sedang, berat, dan panik. Perawat dapat menemukan klien cemas di mana saja di rumah sakit atau lingkup masyarakat.

Strategi coping sebagai bentuk usaha kognitif dan perilaku yang dilakukan untuk mengatur tuntutan internal dan eksternal yang timbul dari hubungan individu dengan lingkungan, yang dianggap menganggu batas-batas yang dimiliki oleh individuTerdapat dua jenis strategi koping yang biasanya digunakan oleh individu. Fokus koping pada emosi (emotion focus coping) adalah mengarahkanrespon kontrol emosi pada situasi yang penuh stres (Pardede, Keliat, Damanik \& Gulo, 2020).

\subsubsection{Etiologi Kecemasan}

\section{Faktor predisposisi}

Stressor predisposisi adalah semua ketegangan dalam kehidupan yang dapat menyebabkan timbulnya kecemasan (Stuart, Keliat \& Pasaribu, 2016). Ketegangan dalam kehidupan tersebut dapat berupa

a. Peristiwa Traumatik, yang dapat memicu terjadinya kecemasan berkaitan dengan krisis yang dialami individu baik krisis perkembangan atau situasional. 
b. Konflik Emosional, yang dialami individu dan tidak terselesaikan dengan baik. Konflik antara id dan superego atau antara keinginan dan kenyataan dapat menimbulkan kecemasan pada individu.

c. Konsep diri terganggu akan menimbulkan ketidakmampuan individu berpikir secara realitas sehingga akan menimbulkan kecemasan.

d. Frustasi akan menimbulkan rasa ketidakberdayaan untuk mengambil keputusan yang berdampak terhadap ego.

e. Gangguan fisik akan menimbulkan kecemasan karena merupakan ancaman terhadap integritas fisik yang dapat mempengaruhi konsep diri individu.

f. Pola mekanisme koping keluarga atau pola keluarga menangani stress akan mempengaruhi individu dalam berespon terhadap konflik yang dialami karena pola mekanisme koping individu banyak dipelajari dalam keluarga.

g. Riwayat gangguan kecemasan dalam keluarga akan mempengaruhi respons individu dalam berespons terhadap konflik dan mengatasi kecemasannya.

h. Medikasi yang dapat memicu terjadinya kecemasan adalah pengobatan yang mengandung benzodiazepin,karena benzodiazepine dapat menekan neurotransmiter gamma amino butyric acid (GABA) yang mengontrol aktivitas neuron di otak yang bertanggung jawab menghasilkan kecemasan.

\section{Faktor presipitasi}

Stresor presipitasi adalah semua ketegangan dalam kehidupan yang dapat mencetuskan timbulnya kecemasan (Stuart, Keliat \& Pasaribu, 2016). Stressor presipitasi kecemasan dikelompokkan menjadi dua bagian, yaitu :

a. Ancaman terhadap integritas fisik.Ketegangan yang mengancam integritas fisik yang meliputi : 
1) Sumber Internal,meliputi kegagalan mekanisme fisiologis sistem imun, regulasi suhu tubuh, perubahan biologis normal (misalnya : hamil).

2) Sumber Eksternal,meliputi paparan terhadap infeksi virus dan bakteri, polutan lingkungan, kecelakaan, kekurangan nutrisi, tidak adekuatnya tempat tinggal.

b. Ancaman terhadap harga diri meliputi sumber internal dan eksternal :

1) Sumber Internal : kesulitan dalam berhubungan interpersonal di rumah dan tempat kerja, penyesuaian terhadap peran baru. Berbagai ancaman terhadap integritas fisik juga dapat mengancam harga diri.

Sumber Eksternal:kehilangan orang yang dicintai, perceraian, perubahan status pekerjaan,tekanan kelompok,sosial budaya.

\subsubsection{Patofisiologi Kecemasan}

Sistem syaraf pusat menerima suatu persepsi ancaman. Persepsi ini timbul akibat adanya rangsangan dari luar dan dalam yang berupa pengalaman masa lalu dan faktor genetik. Kemudian rangsangan dipersepsi oleh panca indra, diteruskan dan direspon oleh sistem syaraf pusat melibatkan jalur cortex cerebri - limbic system - reticular activating system - hypothalamus yang memberikan impuls kepada kelenjar hipofise untuk mensekresi mediator hormonal terhadap target organ yaitu kelenjar adrenal yang kemudian memicu saraf otonom melalui mediator hormonal yang lain (Owen, 2016).

\subsubsection{Rentang Respon}

Menurut Stuart (2006) “menjelaskan rentang respon individu terhadap cemas berfluktuasi antara respon adaptif dan maladaptif. Rentang respon yang paling adaptif adalah antisipasi dimana individu siap siaga untuk beradaptasi dengan cemas yang mungkin muncul. Sedangkan rentang yang paling maladaptif adalah panik dimana individu sudah 
tidak mampu lagi berespon terhadap cemas yang dihadapi sehingga mengalami ganguan fisik, perilaku maupun kognitif. Seseorang berespon adaptif terhadap kecemasannya maka tingkat kecemasan yang dialaminya ringan, semakin maladaptif respon seseorang terhadap kecemasan maka semakin berat pula tingkat kecemasan yang dialaminya, seperti gambar dibawah ini :"

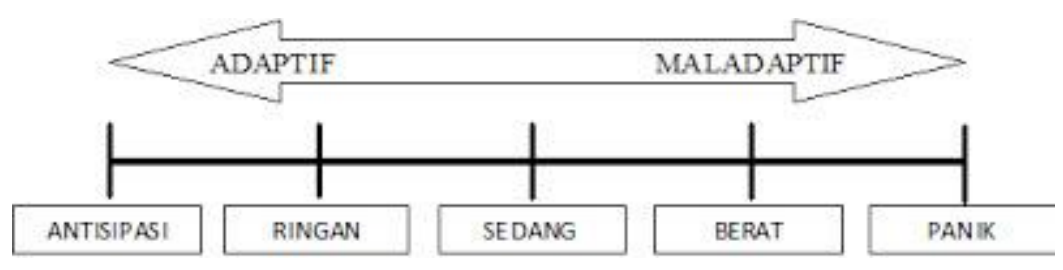

Gambar Rentang Respon Kecemasan (Stuart,2006)

\subsubsection{Tanda dan Gejala Kecemasan}

Menurut Utami, Astuti\& Livana (2017) tanda dan gejala kecemasan adalah :

\section{Respons fisik :}

a. Kardiovaskular : Palpitasi, Jantung Bedebar, Tekanan Darah Meninggi, Denyut Nadi Cepat

b. Pernafasan : Napas Cepat, Napas Pendek, Tekanan Pada Dada, Napas Dangkal, Pembengkakan Pada Tenggorokan, TerengahEngah

c. Neuromuskular : Refleks Meningkat, Insomnia, Tremor, Gelisah, Wajah Tegang, Kelemahan Umum, Kaki Goyah, Gerakan Yang Janggal

d. Gastrointestinal : Anoreksia, Diare/Konstipasi, Mual, Rasa Tidak Nyaman Pada Abdomen

e. Traktur Urinarius : Sering Berkemih Dan Tidak Dapat Menahan Kencing

f. Kulit : Wajah Kemerahan, Berkeringat, Gatal, Rasa Panas Pada Kulit 


\section{Respons Kognitif :}

Lapang persepsi menyempit, tidak mampu menerima rangsang luar, berfokus pada apa yang menjadi perhatiannya

\section{Respons Perilaku :}

Gerakan tersentak-sentak, bicara berlebihan dan cepat, perasaan tidak aman.

\section{Respons Emosi :}

Menyesal, iritabel, kesedihan mendalam, takut, gugup, sukacita berlebihan, ketidakberdayaan meningkat secara menetap, ketidakpastian, kekhawatiran meningkat, fokus pada diri sendiri, perasaan tidak adekuat, ketakutan, distressed, perihatin.

\subsubsection{Penatalaksanaan Kecemasan}

Menurut Hawari (2008) penatalaksanaan ansietas pada tahap pencegahaan dan terapi memerlukan suatu metode pendekatan yang bersifat holistik, yaitu mencangkup fisik (somatik), psikologik atau psikiatrik, psikososial dan psikoreligius. Selengkpanya seperti pada uraian berikut :

1. Upaya meningkatkan kekebalan terhadap stress, dengan cara :

a. Makan makanan yang berigizi dan seimbang

b. Tidur yang cukup

c. Olahraga yang teratur

d. Tidak merokok dan tidak minum minuman keras

\section{Terapi Psikofarmaka}

Terapi psikofarmaka yang sering dipakai adalah obat anti cemas (anxiolytic), yaitu seperti diazepam, clobazam, bromazepam, lorazepam, buspirone $\mathrm{HCl}$, meprobamate dan alprazolam.

3. Terapi Somatik 
Gejala atau keluhan fisik (somatik) sering dijumpai sebagai gejala ikutan atau akibat dari kecemasan yang bekerpanjangan. Untuk menghilangkan keluhan-keluhan somatik (fisik) itu dapat diberikan obat-obatan yang ditujukan pada organ tubuh yang bersangkutan.

4. Psikoterapi

Psikoterapi diberikan tergantung dari kebutuhan individu, antara lain

a. Psikoterapi Suportif

b. Psikoterapi Re-Edukatif

c. Psikoterapi Re-Konstruktif

d. Psikoterapi Kognitif

e. Psikoterapi Psikodinamik

f. Psikoterapi Keluarga

5. Terapi Psikoreligius

Untuk meningkatkan keimanan seseorang yang erat hubungannya dengan kekebalan dan daya tahan dalam menghadapi berbagai problem kehidupan yang merupakan stressor psikososial.

\subsection{Konsep Asuhan Keperawatan}

\subsubsection{Pengkajian}

\section{Faktor Predisposisi}

Berbagai teori telah dikembangkan untuk menjelaskan asal ansietas (Waryuningsih,2021) :

\section{a. Teori Psikoanalitik}

Ansietas adalah konflik emosional yang terjadi antara dua elemen kepribadian,ID dan superego.ID mewakili dorongan insting dan impuls primitif seseorang,sedangkan superego mencerminkan hati nurani seseorang dan dikendalikan oleh norma- norma budaya seseorang.Ego atau aku,berfungsi menengahi hambatan dari dua elemen yang bertentangan dan fungsi ansietas adalah mengingatkan ego bahwa ada bahaya.

\section{b. Teori Interpersonal}


Ansietas timbul dari perasaan takut terhadap tidak adanya penerimaan dari hubungan interpersonal. Ansietas juga berhubungan dengan perkembangan,trauma seperti perpisahan dan kehilangan sehingga menimbulkan kelemahan spesifik.Orang dengan harga diri rendah mudah mengalami perkembangan ansietas yang berat.

\section{c. Teori Perilaku}

Ansietas merupakan produk frustasi yaitu segala sesuatu yang mengganggu kemampuan seseorang untuk mencapai tujuan yang diinginkan.Daftar tentang pembelajaran meyakini bahwa individu yang terbiasa dalam kehidupan dininya dihadapkan pada ketakutan yng berlebihan lebih sering menunjukkan ansietas pada kehidupan selanjutnya.

\section{d. Kajian Keluarga}

Menunjukkan bahwa gangguan ansietas merupakan hal yang biasa ditemui dalam suatu keluarga.Ada tumpang tindih dalam gangguan ansietas dan antara gangguan ansietas dengan depresi.

\section{e. Kajian Biologis}

Menunjukkan bahwa otak mengandung reseptor khusus benzodiazepine. Reseptor ini mungkin membantu mengatur ansietas penghambat dalam aminobutirik. Gamma neuroregulator (GABA) juga mungkin memainkan peran utama dalam mekanisme biologis berhubungan dengan ansietas sebagaimana halnya endorfin. Selain itu telah dibuktikan kesehatan umum seseorang mempunyai akibat nyata sebagai predisposisi terhadap ansietas. Ansietas mungkin disertai dengan gangguan fisik dan selanjutnya menurunkan kapasitas seseorang untuk mengatasi stressor.

\section{Faktor Presipitasi}


Stressor pencetus mungkin berasal dari sumber internal atau eksternal. Stressor pencetus dapat dikelompokkan menjadi 2 kategori (Pratiwi, Widianti \& Solehati, 2017):

a. Ancaman terhadap integritas seseorang meliputi ketidakmampuan fisiologis yang akan datang atau menurunnya kapasitas untuk melakukan aktifitas hidup sehari- hari.

b. Ancaman terhadap sistem diri seseorang dapat membahayakan identitas, harga diri dan fungsi sosial yang terintegrasi seseorang.

\section{Perilaku}

Kecemasan dapat diekspresikan secara langsung melalui perubahan fisiologi dan perilaku dan secara tidak langsung melalui timbulnya gejala atau mekanisme koping dalam upaya melawan kecemasan. Intensitas perilaku akan meningkat sejalan dengan peningkatan tingkat kecemasan.

a. Respon Fisiologis Terhadap Ansietas

\begin{tabular}{|c|c|}
\hline Sistem Tubuh & Respons \\
\hline Kardiovaskuler & $\begin{array}{l}\text { - Palpitasi. } \\
\text { - Jantung berdebar. } \\
\text { - Tekanan darah meningkat dan denyut nadi menurun. } \\
\text { - Rasa mau pingsan dan pada akhirnya pingsan. }\end{array}$ \\
\hline Pernafasan & $\begin{array}{l}\text { - } \text { Napas cepat. } \\
\text { - } \quad \text { Pernapasan dangkal. } \\
\text { - } \quad \text { Rasa tertekan pada dada. } \\
\text { - } \text { Pembengkakan pada tenggorokan. } \\
\text { - } \quad \text { Rasa tercekik. } \\
\text { - } \quad \text { Terengah-engah. }\end{array}$ \\
\hline Neuromuskular & $\begin{array}{l}\text { - } \quad \text { Peningkatan reflek. } \\
\text { - } \quad \text { Reaksi kejutan. }\end{array}$ \\
\hline
\end{tabular}




\begin{tabular}{|c|c|}
\hline & $\begin{array}{l}\text { - } \text { Insomnia. } \\
\text { - Ketakutan. } \\
\text { - Gelisah. } \\
\text { - } \text { Wajah tegang. } \\
\text { - Kelemahan secara umum. } \\
\text { - Gerakan lambat. } \\
\text { - Gerakan yang janggal. }\end{array}$ \\
\hline Gastrointestinal & $\begin{array}{l}\text { - } \text { Kehilangan nafsu makan. } \\
\text { - } \text { Menolak makan. } \\
\text { - } \text { Perasaan dangkal. } \\
\text { - } \text { Rasa tidak nyaman pada abdominal. } \\
\text { - Rasa terbakar pada jantung. } \\
\text { - Nausea. } \\
\text { - } \text { Diare. }\end{array}$ \\
\hline Perkemihan & $\begin{array}{l}\text { - } \quad \text { Tidak dapat menahan kencing. } \\
\text { - } \quad \text { Sering kencing. }\end{array}$ \\
\hline Kulit & $\begin{array}{l}\text { - } \text { Rasa terbakar pada mukosa. } \\
\text { - } \text { Berkeringat banyak pada telapak tangan. } \\
\text { - } \text { Gatal-gatal. } \\
\text { - } \text { Perasaan panas atau dingin pada kulit. } \\
\text { - } \text { Muka pucat dan bekeringat diseluruh tubuh. }\end{array}$ \\
\hline
\end{tabular}

b. Respon Perilaku Kognitif

\begin{tabular}{|l|ll|}
\hline \multicolumn{1}{|c|}{ Sistem } & \multicolumn{2}{c|}{ Respons } \\
\hline Perilaku & $\bullet$ & Gelisah. \\
& $\bullet$ & Ketegangan fisik. \\
& $\bullet$ & Tremor. \\
& $\bullet$ & Gugup. \\
&
\end{tabular}




\begin{tabular}{|c|c|}
\hline & $\begin{array}{l}\text { - } \text { Bicara cepat. } \\
\text { - Tidak ada koordinasi. } \\
\text { - Kecenderungan untuk celaka. } \\
\text { - Menarik diri. } \\
\text { - Menghindar. } \\
\text { - Terhambat melakukan aktifitas. }\end{array}$ \\
\hline Kognitif & $\begin{array}{l}\text { - } \text { Gangguan perhatian. } \\
\text { - Konsentrasi hilang. } \\
\text { - } \text { Pelupa. } \\
\text { - Salah tafsir. } \\
\text { - Adanya bloking pada pikiran. } \\
\text { - Menurunnya lahan persepsi. } \\
\text { - Kreatif dan produktif menurun. } \\
\text { - } \text { Bingung. }\end{array}$ \\
\hline & $\begin{array}{l}\text { - Khawatir yang berlebihan. } \\
\text { - Hilang menilai objektifitas. } \\
\text { - Takut akan kehilangan kendali. } \\
\text { - Takut yang berlebihan. }\end{array}$ \\
\hline Afektif & $\begin{array}{l}\text { - } \text { Mudah terganggu. } \\
\text { - } \text { Tidak sabar. } \\
\text { - Gelisah. } \\
\text { - Tegang. } \\
\text { - Nerveus. } \\
\text { - Ketakutan. } \\
\text { - Alarm. } \\
\text { - Tremor. } \\
\text { - Gugup. } \\
\text { - Gelisah. }\end{array}$ \\
\hline
\end{tabular}




\section{Sumber Koping}

Individu dapat mengalami stress dan ansietas dengan menggerakkan sumber koping tersebut di lingkungan. Sumber koping tersebut sebagai modal ekonomok, kemampuan penyelesaian masalah, dukungan sosial dan keyakinan budaya dapat membantu seseorang mengintegrasikan pengalaman yang menimbulkan stress dan mengadopsi strategi koping yang berhasil (Sulastri, Trilianto \& Ermaneti,2019).

\section{Mekanisme Koping}

Ketika mengalami ansietas individu menggunakan berbagai mekanisme koping untuk mencoba mengatasinya dan ketidakmampuan mengatasi ansietas secara konstruktif merupakan penyebab utama terjadinya perilaku patologis. Ansietas tingkat ringan sering ditanggulangi tanpa yang serius.Tingkat ansietas sedang dan berat menimbulkan 2 jenis mekanisme koping (Sumoked, Wowiling \& Rompas, 2019) :

a. Reaksi yang berorientasi pada tugas, yaitu upaya yang disadari dan berorientasi pada tindakan untuk memenuhi secara realitis tuntutan situasi stress.

b. Mekanisme pertahanan ego, membantu mengatasi ansietas ringan dan sedang, tetapi jika berlangsung pada tingkat sadar dan melibatkan penipuan diri dan distorsi realitas, maka mekanisme ini dapat merupakan respon maladaptif terhadap stress.

\subsubsection{Diagnosa Keperawatan}

Adapun diagnosa yang biasanya muncul adalah :

1. Koping Individu Tidak Efektif

2. Kecemasan

3. Ketidakberdayaan

4. Isolasi Sosial 
5. Perubahan Proses Berfikir

\subsubsection{Intervensi Keperawatan}

\section{Kecemasan}

Tujuan :

- Klien mampu mengenal pengertian penyebab tanda gejala dan akibat

- Klien mampu mengetahui cara mengatasi ansietas

- Klien mampu mengatasi ansietas dengan melakukan latihan relaksasi tarik nafas dalam

- Klien mampu mengatasi ansietas dengan melakukan latihan distraksi

- Klien mampu mengatasi ansietas dengan melakukan hipnotis lima jari

- Klien mampu merasakan manfaat dari latihan yang dilakukan

- Klien mampu membedakan perasaan sebelum dan sesudah latihan

Tindakan :

a. Kaji tanda dan gejala ansietas dan kemampuan klien mengurangi kecemasan

b. Jelaskan tanda dan gejala, penyebab dan akibat dari kecemasan

c. Latihan cara mengatasi kecemasan :

1) Teknik relaksasi napas dalam

2) Distraksi : bercakap-cakap hal positif

3) Hipnotis 5 jari fokus padahal-hal yang positif

d. Bantu klien melakukan latihan sesuai dengan jadwal kegiatan.

\section{Koping tidak efektif}

Tujuan :

- Klien mampu mengetahui perubahan kondisi kesehatan dan kemampuannya mengatasi perubahan 
- Klien mampu mengetahui pengertian tanda dan gejala penyebab serta akibat dari ketidakefektifan koping

- Klien mampu mengetahui cara mengatasi ketidakefektifan koping

- Klien mampu mengatasi masalah secara bertahap

- Klien mampu menggunakan sumber/daya sistem pendukung dalam mengatasi masalah

- Klien mampu merasakan manfaat latihan yang dilakukan

- Klien mampu mengembangkan koping yang efektif klien mampu merasakan manfaat sistem pendukung

Tindakan :

a. Kaji tanda dan gejala ketidakefektifan koping

b. Jelaskan proses terjadinya ketidakefektifan koping

c. Diskusikan koping (upaya atau cara) mengatasi masalah pada masa lalu

d. Koping (upaya) yang berhasil dan tidak berhasil. Berikan pujian

e. Pemanfaatan sumber daya atau sistem pendukung dalam mengatasi masalah

f. Latihan menggunakan upaya menyelesaikan masalah saat ini dengan menggunakan cara lama yang berhasil atau cara baru.

- Buat daftar masalah yang dihadapi

- Buat daftar cara (lama dan baru) yang akan digunakan

- Pilih, latih, dan jadwalkan cara yang akan digunakan untuk masalah yang dihadapi

- Evaluasi hasil jika berhasil dibudidayakan jika kurang berhasil dipilih cara lain pada daftar cara nomor kedua

g. Latih menggunakan sistem pendukung yang teratur

h. Beri motivasi dan pujian atas keberhasilan klien mengatasi masalah 



\section{BAB 3}

\section{TINJAUAN KASUS}

\subsection{Pengkajian Keperawatan}

\begin{tabular}{|l|c|}
\hline Nama : Ny.G & Kondisi saat SMRS: lemas, takut, gelisah. \\
Usia : 58 tahun & Kondisi saat ini : \\
Tahun no reg : - & Ny.G mengeluh badannya terasa lemas, kehilangan selera makan, tekanan \\
Ruangan : - & darah tinggi sehingga Ny.G tidak mampu melakukan aktivitas seperti biasanya, \\
Tgl masuk rs: - & hingga membuat Ny.G merasa pusing, takut, gelisah dan tidak dapat \\
Tgl pengkajian : 6 Oktober 2021 & melakukan aktifitas seperti biasa. \\
Alamat: Subulussalam & \\
\hline
\end{tabular}

\subsubsection{Faktor Predisposisi Dan Faktor Presipitasi}

\begin{tabular}{|l|l|l|l|l|}
\hline \multicolumn{1}{|c|}{ Faktor predisposisi } & Faktor presipitasi & \multicolumn{2}{l|}{ STRESSOR } \\
\cline { 2 - 4 } & Nature & Origin & $\begin{array}{l}\text { Number \& } \\
\text { Timing }\end{array}$ & \\
\hline $\begin{array}{l}\text { Biologis: } \\
\text { 1. Hipertensi } \\
\text { 2. Ny. G menderita hipertensi 2 tahun yang lalu }\end{array}$ & $\begin{array}{l}\text { Badannya terasa } \\
\text { lemas, kehilangan }\end{array}$ & Internal & $\begin{array}{l}\text { Sejak } \\
\text { minggu yang } \\
\text { lalu }\end{array}$ & $\bullet$ Hipertensi \\
\hline
\end{tabular}




\begin{tabular}{|c|c|c|c|c|}
\hline $\begin{array}{l}\text { 3. Ny. G sering mengkonsumsi makanan tinggi garam } \\
\text { 4. Ny. G tidak rutin check up kepelayanan kesehatan }\end{array}$ & $\begin{array}{lr}\text { selera } & \text { makan, } \\
\text { tekanan } & \text { darah } \\
\text { tinggi } & \end{array}$ & & & \\
\hline $\begin{array}{l}\text { Psikologis : } \\
\text { 1. Ny.G memiliki kepribadia yang terbuka setiap ada } \\
\text { masalah akan dibicarakan dengan suaminya } \\
\text { 2. Ny.G merasa pusing, mudah lelah, dan juntung } \\
\text { berdebar kencang }\end{array}$ & $\begin{array}{lrr}\text { - Merasa } & \text { takut, } \\
\text { gelisah } & \text { dan tidak } \\
\text { dapat } & \text { melakukan } \\
\text { aktifitas } & \text { seperti } \\
\text { biasa. } & \\
\end{array}$ & Internal & $\begin{array}{lr}\text { Sejak } & 3 \\
\text { minggu } & \text { yang } \\
\text { lalu }\end{array}$ & $\begin{array}{l}\text { - Cemas, takut, } \\
\text { lemas. }\end{array}$ \\
\hline $\begin{array}{l}\text { Sosiocultural : } \\
\text { - Ny.G seorang perempuan umur } 45 \text { tahun } \\
\text { - Ny .G menikah dan memiliki } 2 \text { orang anak } \\
\text { - } \quad \text { Ny.G merupakan ibu rumah tangga } \\
\text { - } \\
\text { Sebelumnya Ny.G aktif terlibat dalam kegiatan } \\
\text { dilingkungan tempat tinggal seperti perwiritan atau } \\
\text { pengajian dilingkungan rumah } \\
\text { - Ny G merupakan orang jawa dan menurut Ny. G tidak } \\
\text { - } \text { ada kebiasaan yang bertentangan dengan kesehatan } \\
\text { - Ny.G beragama islam dan taat menjalankan ibadah } \\
\text { Nyang check up tentang penyakitnya }\end{array}$ & $\begin{array}{ll}\text { - } & \text { Kebutuhan } \\
\text { dibantu } & \text { hidup } \\
\text { keluarga } & \text { oleh } \\
\end{array}$ & Eksternal & Saat ini & $\begin{array}{l}\text { - Merasa malu } \\
\text { dan cemas } \\
\text { terhadap } \\
\text { penyakitnya } \\
\text { dan } \\
\text { pengobatan. }\end{array}$ \\
\hline
\end{tabular}

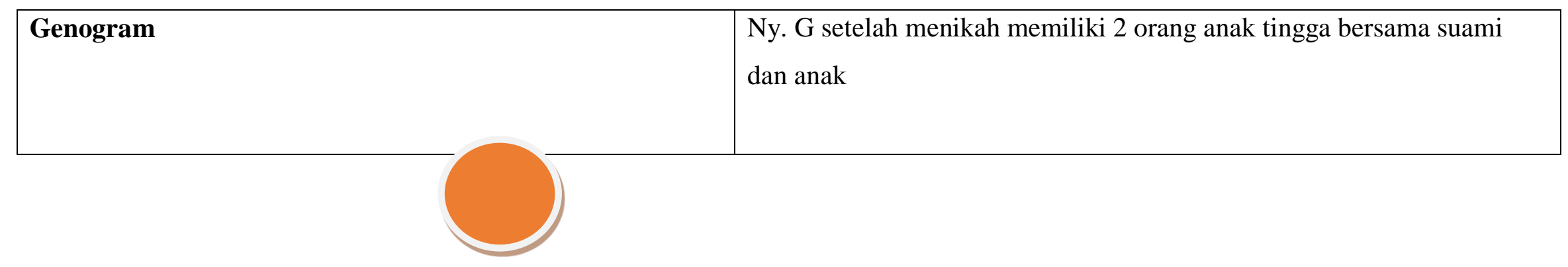




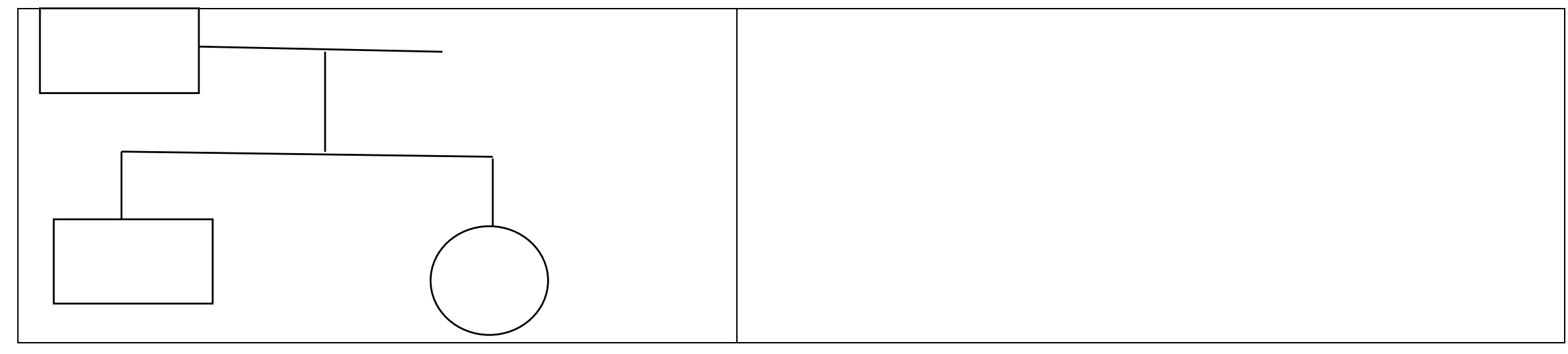

Ket :

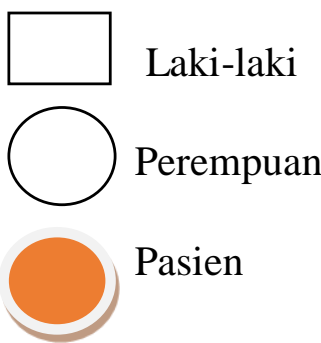

3.1.2 Penilaian (Respon)Terhadap Stressor

\begin{tabular}{|c|c|c|c|c|c|c|}
\hline STRESSOR & KOGNITIF & AFEKTIF & FISIOLOGIS & PERILAKU & SOSIAL & DIAGNOSA \\
KEPERAWATAN
\end{tabular}




\begin{tabular}{|c|c|c|c|c|c|c|}
\hline $\begin{array}{l}\text { BIOLOGIS } \\
\text { - } \\
\text { (Hipert } \\
\text { ensi) }\end{array}$ & $\begin{array}{l}\text { - Menurut } \\
\text { Ny.G } \\
\text { penyakit } \\
\text { Hipertensi } \\
\text { diakibatkan } \\
\text { karena } \\
\text { mengkonsu } \\
\text { msi } \\
\text { makanan } \\
\text { tinggi } \\
\text { garam } \\
\text { Tidak } \\
\text { tahu apa } \\
\text { yang } \\
\text { harus } \\
\text { dilakukan } \\
\text { untuk } \\
\text { penyakitn } \\
\text { ya } \\
\text { Mengang } \\
\text { gap } \\
\text { penyakit } \\
\text { yang } \\
\text { diderita } \\
\text { serius }\end{array}$ & $\begin{array}{l}\text { - Ny.G } \\
\text { merasa } \\
\text { sedih dan } \\
\text { juga } \\
\text { bingung } \\
\text { dengan } \\
\text { kondisi } \\
\text { penyakitny } \\
\text { a saat ini }\end{array}$ & $\begin{array}{l}\text { - } \text { Cemas } \\
\text { - Sulit tidur } \\
\text { - Tidak } \\
\text { nafsu } \\
\text { makan } \\
\text { - Ny. G } \\
\text { tampak } \\
\text { lemas } \\
\text { - Pemeriksaa } \\
\text { n TTV } \\
\text { TD: } 160 / 90 \\
\text { mmhg } \\
\text { N : } 88 \text { x / } \\
\text { menit } \\
\text { P : } 22 \quad \text { x / } \\
\text { menit } \\
\text { S: } 36{ }^{0} \mathrm{C}\end{array}$ & $\begin{array}{ll}\text { - } & \text { Ny. G } \\
\text { jarang } \\
\text { kontrol ke } \\
\text { rumah } \\
\text { sakit } \\
\text { - } \\
\text { Ekspresi } \\
\text { muka } \\
\text { lesu } \\
\text { - Ny.G } \\
\text { tampak } \\
\text { lemasdan } \\
\text { gemetaran }\end{array}$ & $\begin{array}{l}\text { - Pasien } \\
\text { mendatangi } \\
\text { dan } \\
\text { menggunaka } \\
\text { n fasilitas } \\
\text { kesehatan } \\
\text { yang ada } \\
\text { untuk } \\
\text { mencari } \\
\text { kesembuhan } \\
\text { terhadap } \\
\text { masalah yang } \\
\text { dihadapi saat } \\
\text { ini }\end{array}$ & - Ansietas \\
\hline $\begin{array}{l}\text { PSIKOLOG } \\
\text { IS } \\
\text { - Sedih, } \\
\text { cemas, }\end{array}$ & 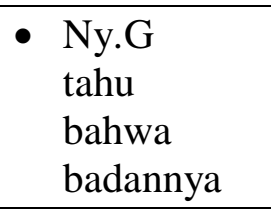 & $\begin{array}{l}\text { - Merasa } \\
\text { kesal } \\
\text { dengan } \\
\text { penyakitny }\end{array}$ & $\begin{array}{l}\text { - Sakit kepala } \\
\text { - Sulit tidur } \\
\text { dan sering } \\
\text { terbangun }\end{array}$ & $\begin{array}{l}\text { - Tampak } \\
\text { cemas dan } \\
\text { tidaktenan } \\
\mathrm{g}\end{array}$ & $\begin{array}{l}\text { - Hubungan } \\
\begin{array}{l}\text { Ny. G G } \\
\text { dengan }\end{array} \\
\text { keluarga }\end{array}$ & - Ansietas \\
\hline
\end{tabular}




\begin{tabular}{|c|c|c|c|c|c|c|}
\hline $\begin{array}{l}\text { lemas dan } \\
\text { Kehilanga } \\
\text { n selera } \\
\text { makan } \\
\text { dengan } \\
\text { kondisi } \\
\text { penyakit } \\
\text { dan } \\
\text { peng } \\
\text { obata } \\
\text { n } \\
\text { serta } \\
\text { Perawatan } \\
\text { nya }\end{array}$ & $\begin{array}{l}\text { terasa } \\
\text { lemas, } \\
\text { kehilanga } \\
\text { n selera } \\
\text { makan, } \\
\text { tekanan } \\
\text { darah } \\
\text { tinggi } \\
\text { sehingga } \\
\text { Ny. G } \\
\text { tidak } \\
\text { mampu } \\
\text { melakuka } \\
\text { n } \\
\text { aktivitas } \\
\text { seperti } \\
\text { biasanya, } \\
\text { hingga } \\
\text { membuat } \\
\text { Ny. G } \\
\text { merasa } \\
\text { takut, } \\
\text { gelisah } \\
\text { dan tidak } \\
\text { dapat } \\
\text { melakuka } \\
\text { n aktifitas } \\
\text { seperti } \\
\text { biasa. } \\
\text { - Ny. G }\end{array}$ & $\begin{array}{l}\text { a yang } \\
\text { tidak } \\
\text { sembuh- } \\
\text { sembuh }\end{array}$ & $\begin{array}{l}\text { apabila tidur } \\
\text { - Tidak } \\
\text { nafsu } \\
\text { makan } \\
\text { - Ny. G } \\
\text { tampak } \\
\text { lemas } \\
\text { - Wajah Ny. } \\
\text { G tampak } \\
\text { lemas } \\
\text { - Pemeriksaa } \\
\text { n TTV } \\
\text { TD: } 145 / 90 \\
\text { mmhg } \\
\mathrm{N}: 88 \quad \text { x / } \\
\text { menit } \\
\text { P : } 20 \quad \text { x / } \\
\text { menit } \\
\text { S: } 37^{0} \mathrm{C}\end{array}$ & 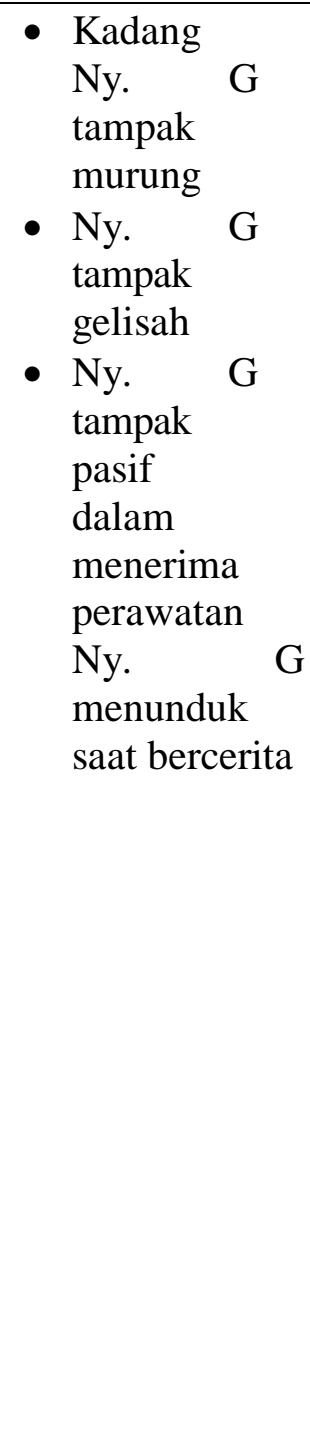 & $\begin{array}{l}\text { baik } \\
\text { - Sikap Ny. G } \\
\text { pasif dalam } \\
\text { menerima } \\
\text { perawatan }\end{array}$ & $\begin{array}{l}\text { - Ketidakberdaya } \\
\text { an }\end{array}$ \\
\hline
\end{tabular}




\begin{tabular}{|c|c|c|c|c|c|c|}
\hline & $\begin{array}{l}\text { mengaku } \\
\text { bosan } \\
\text { berada di } \\
\text { rumah } \\
\text { sakit } \\
\text { Ny. G } \\
\text { tidak tahu } \\
\text { pengobata } \\
\text { n seperti } \\
\text { apa lagi } \\
\text { yang dapat } \\
\text { dilakukan } \\
\text { untuk } \\
\text { mengobati } \\
\text { penyakitn } \\
\text { ya }\end{array}$ & & & & & \\
\hline $\begin{array}{l}\text { SOSIAL } \\
\text { BUDAYA } \\
\text { • Ny. G } \\
\text { merasa } \\
\text { memikirkan } \\
\text { Keluarga } \\
\text { yang masih } \\
\text { yang harus } \\
\text { menjaga dan } \\
\text { merawatnya } \\
\text { setiap hari. }\end{array}$ & $\begin{array}{l}\text { - Ny. G } \\
\text { merasa } \\
\text { harga } \\
\text { dirinya } \\
\text { rendah } \\
\text { keadaanny } \\
\text { a dengan } \\
\text { keadaanyan } \\
\text { g tidak bisa } \\
\text { bekerja } \\
\text { bingung } \\
\text { memikirka } \\
\text { n anak- }\end{array}$ & $\begin{array}{l}\text { - Merasa } \\
\text { khawatir } \\
\text { dan sedih } \\
\text { kepada } \\
\text { suami } \\
\text { yang } \\
\text { merawatn } \\
\text { ya setiap } \\
\text { hari } \\
\text { - Merasa } \\
\text { bersalah } \\
\text { karena } \\
\text { merasa }\end{array}$ & $\begin{array}{l}\text { - Pusing } \\
\text { - } \text { Mual } \\
\text { - Mulut } \\
\text { tampak } \\
\text { kering } \\
\text { - Sulit tidur } \\
\text { - Tidak } \\
\text { nafsu } \\
\text { makan } \\
\text { - Ny. G } \\
\text { tampak } \\
\text { lemas }\end{array}$ & $\begin{array}{ll}\text { - } & \text { Ny. } \\
\text { tampak } & \mathrm{G} \\
\text { gelisah } & \end{array}$ & 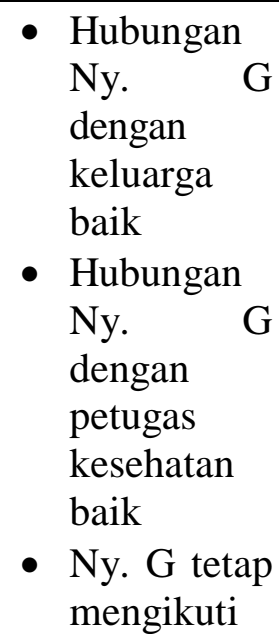 & $\begin{array}{ll}\text { - } & \text { Defisit } \\
\text { Perawatan } \\
\text { Diri }\end{array}$ \\
\hline
\end{tabular}




\begin{tabular}{|c|c|c|c|}
\hline $\begin{array}{l}\text { anak, } \\
\text { menurut } \\
\text { pasien, } \\
\text { dukungan } \\
\text { keluarga } \\
\text { nomor satu } \\
\text { - Ny. G } \\
\text { berfikir ia } \\
\text { selalu } \\
\text { merepotk } \\
\text { an } \\
\text { Keluarga } \\
\text { bila } \\
\text { terlalu } \\
\text { lama } \\
\text { dalam } \\
\text { keadaan } \\
\text { seperti ini } \\
\text { Merasa } \\
\text { kasihan } \\
\text { kepada } \\
\text { keluarga } \\
\text { yang harus } \\
\text { menjaga } \\
\text { dan } \\
\text { merawat } \\
\text { klien }\end{array}$ & $\begin{array}{l}\text { merepotk } \\
\text { an suami } \\
\text { - Merasa } \\
\text { bosan } \\
\text { dengan } \\
\text { keadaan } \\
\text { sekarang }\end{array}$ & $\begin{array}{l}\text { - Wajah Ny. } \\
\text { G tampak } \\
\text { pucat } \\
\text { Pemeriksaan }\end{array}$ & $\begin{array}{l}\text { program } \\
\text { pengobatan }\end{array}$ \\
\hline
\end{tabular}




\begin{tabular}{|l|c|}
\hline Pohon masalah & \multicolumn{1}{|c|}{ Ketidakberdayaan } \\
Kecemasan \\
Defisit Perawatan Diri \\
\hline
\end{tabular}

3.1.3 Sumber Koping

\begin{tabular}{|c|c|c|c|c|c|}
$\begin{array}{c}\text { DIAGNOSA } \\
\text { KEPERAWATAN }\end{array}$ & PERSONAL ABILITY & SOSIAL SUPPORT & $\begin{array}{c}\text { MATERIAL } \\
\text { ASSETS }\end{array}$ & POSITIE BELIEFS & TERAPI \\
\hline
\end{tabular}




\begin{tabular}{|c|c|c|c|c|c|}
\hline Ansietas & $\begin{array}{l}\text { - } \mathrm{Ny.} \mathrm{G} \mathrm{mampu} \\
\text { mengungkapkan } \\
\text { perasaancemas } \\
\text { - Ny. G mengatakan } \\
\text { bila cemasnya } \\
\text { memuncak maka ia } \\
\text { akan sholat dan } \\
\text { berdoa }\end{array}$ & $\begin{array}{l}\text { - Ny. G } \\
\text { mendapat } \\
\text { dukungan dari } \\
\text { keluarga untuk } \\
\text { kesembuhanny } \\
\text { a dan keluarga } \\
\text { Ny. G } \\
\text { bergantian } \\
\text { merawat pasien }\end{array}$ & $\begin{array}{l}\text { - Sosial ekonomi } \\
\text { Ny.G menengah } \\
\text { Pengobatan } \\
\text { ditanggung } \\
\text { BPJS } \\
\text { - Jarak rumah } \\
\text { Ny. G dengan } \\
\text { tempat } \\
\text { pelayanan } \\
\text { kesehatan lebih } \\
\text { kurang } 600 \\
\text { meter }\end{array}$ & $\begin{array}{l}\text { - Ny. G percaya } \\
\text { bahwa petugas } \\
\text { kesehatan akan } \\
\text { membantunya } \\
\text { - Ny. G berharap } \\
\text { cepat sembuh agar } \\
\text { tidak merepotkan } \\
\text { keluarga }\end{array}$ & $\begin{array}{l}\text { Terapi spesialis: } \\
\text { - Relaksasi } \\
\text { progresif } \\
\text { - Psikoedukas } \\
\text { i keluarga } \\
\text { - Behavior } \\
\text { therapy } \\
\text { - Psikoedukas } \\
\text { i keluarga }\end{array}$ \\
\hline $\begin{array}{l}\text { Penampilan peran } \\
\text { tidak efektif }\end{array}$ & $\begin{array}{l}\text { - Ny. G dapat } \\
\text { menyebutkan } \\
\text { penyebab } \\
\text { penampilan peran } \\
\text { tidak efektif } \\
\text { - Ny. G } \\
\text { menganggap } \\
\text { suami tidak } \\
\text { mampu sebagai } \\
\text { pengganti } \\
\text { akibat kondisi } \\
\text { yang berubah }\end{array}$ & & & $\begin{array}{l}\text { - Ny. G selalu } \\
\text { beribadah dan } \\
\text { berdoa untuk } \\
\text { kesembuhan } \\
\text { penyakitnya } \\
\text { - Ny. G yakin, bila } \\
\text { ia mengikuti } \\
\text { petunjuk dan } \\
\text { saran dari petugas } \\
\text { kesehatan maka ia } \\
\text { akan cepat } \\
\text { sembuh } \\
\text { Ny. G yakin } \\
\text { keluarga } \\
\text { mendukung } \\
\text { supaya lekas }\end{array}$ & \\
\hline
\end{tabular}




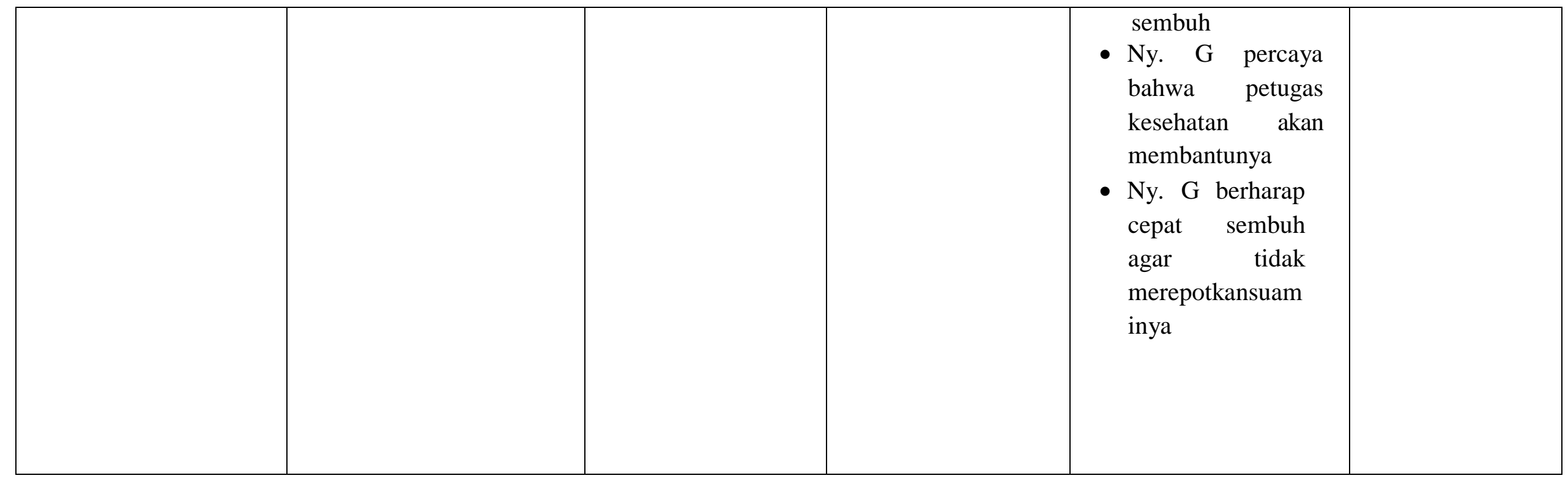




\begin{tabular}{|c|c|c|c|c|c|}
\hline $\begin{array}{l}\text { Kurang } \\
\text { pengetahuan }\end{array}$ & $\begin{array}{l}\text { - Ny. G mampu } \\
\text { mengenal dan } \\
\text { menilai penyakitnya } \\
\text { - Ny. G mampu } \\
\text { melatih cara } \\
\text { hidup sehat }\end{array}$ & $\begin{array}{l}\text { - } \mathrm{Ny.} \mathrm{G} \\
\text { mendapat } \\
\text { dukungan dari } \\
\text { keluarga } \\
\text { untuk } \\
\text { kesembuhann } \\
\text { ya terutama } \\
\text { dari keluarga } \\
\text { nya } \\
\text { - Keluarga Ny. G } \\
\text { bergantian } \\
\text { menjaga dan } \\
\text { mengunjungipa } \\
\text { sien }\end{array}$ & $\begin{array}{l}\text { - Sosial ekonomi } \\
\text { Ny. G } \\
\text { menengah } \\
\text { - Ny. G tinggal } \\
\text { di rumah } \\
\text { sendiri, } \\
\text { rumah } \\
\text { permanen } \\
\text { - Sarana } \\
\text { dan } \\
\text { prasarana } \\
\text { tersedia } \\
\text { - Biaya } \\
\text { pengobatan } \\
\text { ditanggung oleh } \\
\text { asuransi BPJS } \\
\text { Jarak rumah } \\
\text { Ny. G dengan } \\
\text { tempat } \\
\text { pelayanan } \\
\text { kesehatan } \\
\text { (RSMM) lebih } \\
\text { kurang } 500 \\
\text { meter }\end{array}$ & $\begin{array}{l}\text { - Ny. G percaya } \\
\text { bahwa petugas } \\
\text { kesehatan akan } \\
\text { membantunya } \\
\text { - Ny. G berharap } \\
\text { cepat sembuh } \\
\text { agar tidak } \\
\text { merepotkan } \\
\text { keluarganya } \\
\text { - Ny. G selalu } \\
\text { sholat dan tidak } \\
\text { lupa berdoa } \\
\text { untuk } \\
\text { kesembuhan } \\
\text { penyakitnya } \\
\text { Ny. G yakin, bila } \\
\text { ia mengikuti } \\
\text { petunjuk dan } \\
\text { saran } \\
\text { petugas dari } \\
\text { kesehatan maka } \\
\text { ia akan cepat } \\
\text { sembuh } \\
\text { Ny. G yakin } \\
\text { keluarga }\end{array}$ & 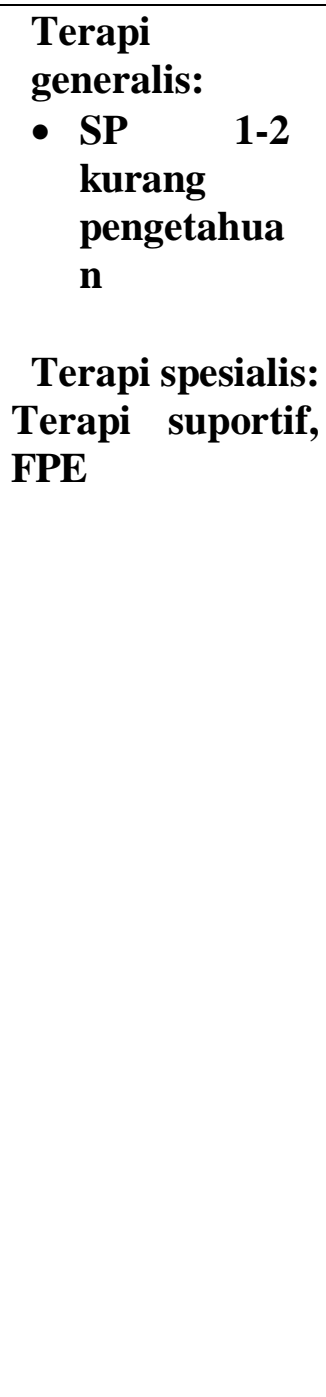 \\
\hline
\end{tabular}




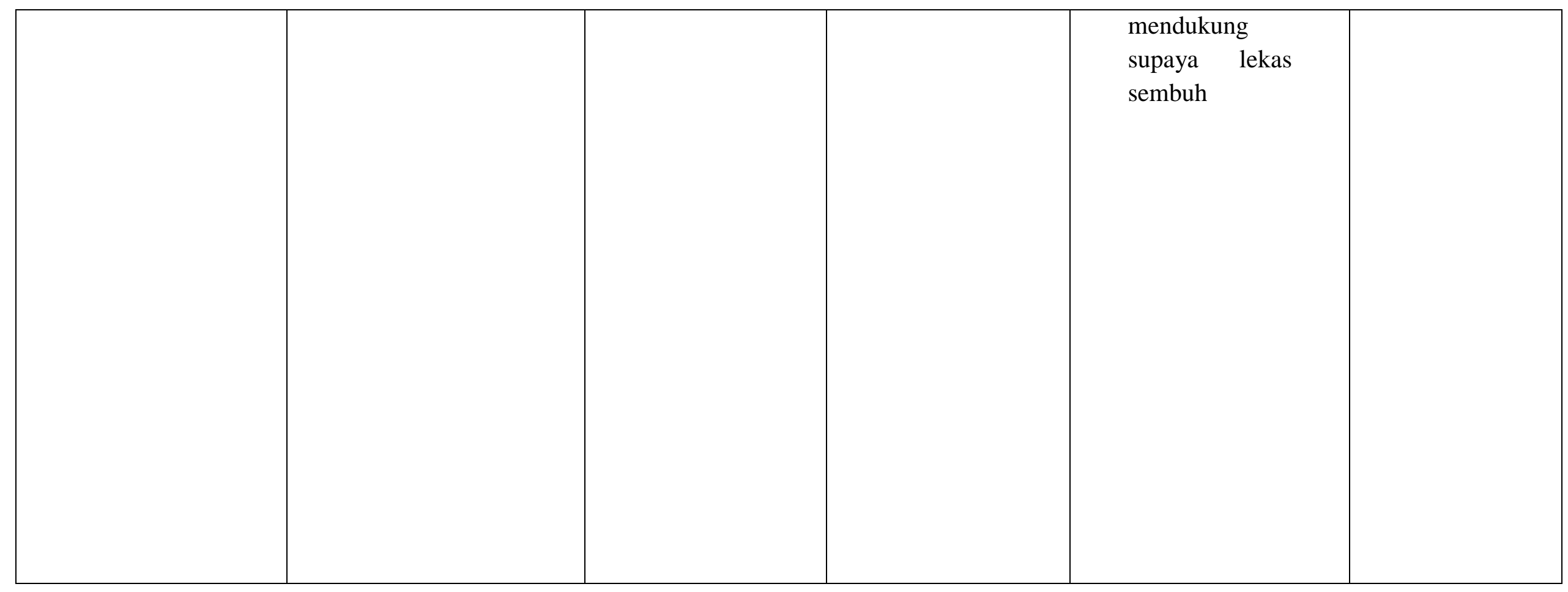




\subsubsection{Mekanisme Koping}

\begin{tabular}{|c|c|}
\hline $\begin{array}{l}\text { HAL YANG } \\
\text { DILAKUKAN }\end{array}$ & ANALISA \\
\hline $\begin{array}{l}\text { - Ny. G mengatakan bila ada masalah, maka ia akan membicarakan } \\
\text { dengan suami dan keluarga untuk mencari jalan keluarnya } \\
\text { - Bila sakit Ny. G berobat ke pelayanan kesehatan } \\
\text { - Ny. G taat menjalankan ibadah sesuai dengan keyakinannya } \\
\text { - Ny. G selalu berdoa kepada Allah SWT untuk kesembuhannya }\end{array}$ & $\begin{array}{l}\text { - Konstruktif: } \\
\checkmark \quad \text { Ny. G mengatakan bila ada masalah, maka ia akan } \\
\text { membicarakan dengan keluarga untuk mencari jalan } \\
\text { keluarnya } \\
\checkmark \text { Bila sakit Ny. G berobat ke pelayanan kesehatan } \\
\checkmark \quad \text { Ny. G taat menjalankan ibadah sesuai } \\
\text { dengan keyakinannya } \\
\checkmark \text { Ny. G selalu berdoa kepada Allah SWT } \\
\text { untuk kesembuhannya. }\end{array}$ \\
\hline & - Destruktif : - \\
\hline
\end{tabular}




\subsubsection{Status Mental}

\begin{tabular}{|l|l|}
\hline 1. Penampilan & Bersih, lemas, rapi \\
\hline 2. Pembicaraan & Ramah dan mau menceritakan semua hal yang dialami \\
\hline 3. Aktivitas motoric & Mampu berinteraksi \\
\hline 4. Interaksi selamawawancara & Ada kontak mata saat wawancara \\
\hline 5. Alam perasaan & Sedih, merasa cemas, takut, pusing dan bingung mengenai penyakit \\
\hline 6. Afek & Datar \\
\hline 7. Persepsi & Tidak ada gangguan persepsi dan sensori \\
\hline 8. Isi piker & Tidak ada gangguan isi piker \\
\hline 9. Proses piker & Tidak ada ganggu proses piker \\
\hline 10. Tingkat kesadaran & Normal \\
\hline 11. Daya ingat & Normal \\
\hline 12. Kemampuan berhitung & Tidak ada gangguan dalam berhitung \\
\hline 13. Penilaian & Ny. G mengambil keputusan saat merasa sakit dengan beribadah dan berdoa \\
\hline 14. Daya tilik diri & Ny. G menyadari memang merasa cemas \\
& \\
\hline
\end{tabular}

Kesimpulan : Mental Status Examination (MSE) tidak ada masalah gangguan jiwa, gangguan Ny. T lebih kepada Gangguan Mental Emosional (GME/Psikososial) 


\subsection{Diagnosa Dan Terapi}

\section{DIAGNOSA KEPERAWATAN DAN TERAPI KEPERAWATAN}

\section{Ansietas}

Sp1: Mendiskusikan penyebab,terjadinya proses terjadi, tanda gejala,akibat

Sp2 : Melatih teknik releksasi fisik

Sp3: Melatih mengatasi ansietas dengan distraksi dan hipnotis lima

Sp4 :Melatih mengatasi ansietas memalui kegiatan spritual

2. Ketidakberdayaan

Sp1: Assesment ketidakberdayaan dan latihan berpikir positif

Sp2: Manfaat mengembangkan harapan positif dan latihan mengontrol perasaan

Terapi spesialis:

Terapi kognitif

3. Kurang pengetahuan

Terapi suportif, FPE

\subsection{Implementasi Tindakan Keperawatan Dan Evaluasi}

\begin{tabular}{|c|c|}
\hline IMPLEMENTASI KEPERAWATAN & EVALUASI (SOAP) \\
\hline $\begin{array}{l}\text { Tanggal : } 06 \text { oktober } 2021 \\
\text { Jam : } 10.00 \text { wib } \\
\text { - Kaji tanda dan gejala ansietas dan kemampuan } \\
\text { pasien mengurangi kecemasannya } \\
\text { - Menjelaskan tanda dan gejala, penyebab dan } \\
\text { akibat dari kecemasan }\end{array}$ & $\begin{array}{l}\text { S : Senang } \\
\text { O : } \\
\text { - Klien mampu mengkaji tanda dan gejala ansietas dan } \\
\text { mempu mengurangi kecemasannya } \\
\text { - } \text { Klien mampu menjelaskan tanda dan gejala, penyebab } \\
\text { dan akibat dari kecemasannya } \\
\text { A : Ansietas (+) }\end{array}$ \\
\hline
\end{tabular}


- Latihan cara mengatasi kecemasan :

1. Teknik relaksasi napas dalam

2. Distraksi : bercakap-cakap hal positif

3. Hipnotis 5 jari, fokus pada hal-hal yang positif

- Bantu pasien melakukan latihan sesuai dengan jadwal kegiatan.

P :

Evaluasi

- Latihan cara mengatasi kecemasan :

a. Teknik relaksasi napas dalam 3x sehari

b. Distraksi : bercakap-cakap hal positif

c. Hipnotis 5 jari, fokus pada hal-hal yang positif

- Latihan sesuai dengan jadwal kegiatan 3x/hari

Tanggal : 07 Oktober 2021

Jam : 10.00 wib

a. Latihan cara mengatasi kecemasan:

1. Teknik relaksasi napas dalam

2. Distraksi : bercakap-cakap hal positif

3. Hipnotis 5 jari, fokus pada hal-hal yang positif

b. Bantu klien melakukan latihan sesuai dengan jadwal kegiatan

\section{S : Senang}

$\mathrm{O}$ :

- Klien mampu rileks dan tidak gelisah lagi

- Klien mampu menjelaskan kembali penjelasan yang sudah diberikan

- Klien mampu melakukan teknik napas dalam

- Klien mampu melakukan distraksi

- Klien mampu melakukan hipnotis 5 jari

A : Ansietas (-)

$\mathrm{P}$ :

- Latihan sesuai jadwal kegiatan

- Terapi perilaku

- Terapi kognitif 


\begin{tabular}{|c|c|}
\hline & - Pendidikan kesehatan \\
\hline $\begin{array}{l}\text { Tanggal : } 08 \text { Oktober } 2021 \\
\text { Jam : } 10.00 \text { wib } \\
\text { a. Menenangkan pasien } \\
\text { b. Memahami keadaan pasien } \\
\text { c. Mendiskusikan penyebab, terjadinya proses } \\
\text { terjadi tanda gejala, akibat } \\
\text { d. Mengkaji ketidakberdayaan } \\
\text { e. Melatih pasien mengotrol ketidakberdayaan } \\
\text { dengan melatih berfikir positif }\end{array}$ & $\begin{array}{l}\text { S : Senang } \\
\text { O : } \\
\text { - Klien mampu mengidentifikasi hal positif yang dimiliki } \\
\text { - } \text { Klien mampu menceritakan ketidakberdayaan, } \\
\quad \text { penyebabnya } \\
\text { A : Ketidakberdayaan (+) } \\
\text { P : } \\
\text { - Latihan berfikir positif 3x sehari } \\
\text { - Latihan perawatan diri sendiri } \\
\text { - Latihan melakukan aktivitas : mencuci baju }\end{array}$ \\
\hline $\begin{array}{l}\text { Tanggal : } 09 \text { Oktober } 2021 \\
\text { Jam : } 10.00 \text { wib } \\
\text { a. Menenangkan pasien } \\
\text { b. Memahami keadaan pasien } \\
\text { c. Mendiskusikan penyebab, terjadinya proses } \\
\text { terjadi tanda gejala, akibat } \\
\text { d. Mengkaji ketidakberdayaan }\end{array}$ & $\begin{array}{l}\text { S : Senang } \\
\text { O : } \\
\text { - Klien mampu megidentifikasi hal positif yang dimiliki } \\
\text { - Klien mampu menceritakan ketidakberdayaan } \\
\text { berdayaannya, penyebabnya } \\
\text { A : Ketidakberdayaan (-) } \\
\text { P : }\end{array}$ \\
\hline
\end{tabular}


e. Melakukan Sp2 manfaat mengembangkan harapan positif dan latihan mengontrol perasaan, afrimasi positif
- Latihan afirmasi positif 3x sehari

- Pendidikan kesehatan 


\section{BAB 4 \\ PEMBAHASAN}

Setelah penulis melaksanakan asuhan keperawatan kepada $\mathrm{Ny}$. G dengan Kecemasan di subulussalam maka penulis pada BAB ini akan membahas kesenjangan antara teoritis dengan tinjauan kasus. Pembahasan dimulai melalui tahapan proses keperawatan yaitu pengkajian, diagnosa keperawatan, perencanaan, pelaksanaan dan evaluasi.

\subsection{Tahap Pengkajian}

Selama pengkajian dilakukan pengumpulan data dari beberapa sumber, yaitu dari pasien dan tetangga sekitar. Maka penulis melakukan pendekatan kepada pasien melalui komunikasi teraupetik yang lebih terbuka membantu klien untuk memecahkan perasaannya dan juga melakukan observasi kepada pasien. Adapun upaya tersebut yaitu :

a. Melakukan pendekatan dan membina hubungan saling percaya diri pada klien agar klien lebih terbuka dan lebih percaya dengan menggunakan perasaan.

b. Mengadakan pengkajian klien dengan wawancara Dalam pengkajian ini, penulis tidak menemukan kesenjangan karena ditemukan hal sama seperti: diteori: Kecemasan adalah keadaan emosi dan pengalaman subyektif individu, tanpa objek yang spesifik karena ketidaktahuan dan mendahului pengalamanya yang baru seperti penyakitnya saat ini

\subsection{Tahap perencanaan}

Perencanaan dalam proses keperawatan lebih dikenal dengan rencana asuhan keperawatan yang merupakan tahap selanjutnya setelah pangkajian dan penentuan diagnosa keperawatan. Pada tahap perencanaan penulis hanya menyusun rencana tindakan keperawatan sesuai dengan pohon masalah keperawatan yaitu : Kecemasan. Pada tahap ini antara tinjauan teoritis dan tinjaun kasus tidak ada kesenjangan sehingga penulis dapatmelaksanakan 
tindakan seoptimal mungkin dan didukung dengan seringnya bimbingan dengan pembimbing.

Secara teoritis digunakan cara strategi pertemuan sesuai dengan diagnosa keperawatan yang muncul saat pengkajian. Adapun upaya yang dilakukan penulis yaitu :

1. Klien mengungkapkan ketidakpastian tentang fluktuasi tingkat energi dan bersikap pasif.

2. Klien menunjukan sikap cemas, gelisan dan takut terhadap perburukan fisik yang terjadi dengan mengabaikan kepatuhan pasien terhadap program pengobatan.

3. Klien mengalami ketergantungan pada orang lain yang dapat mengakibatkan ititabilitas, ketidaksukaan, marah dan rasa bersalah. Klien tidak melakukan praktik perawatan diri ketika ditantang. Klien tidak ikut memantau kemajuan pengobatan. Klien menunjukan ekspresi ketidakpuasan terhadap ketidakmampuan melakukanaktivitas atau tugas sebelumnya. Klien menunjukan ekspresi keraguan tantang performa peran.

\subsection{Tahap Implementasi}

Pada tahap implementasi, penulis hanya mengatasi 1 masalah keperawatan yakni: diagnosa keperawatan Kecemasan merupakan respon emosional terhadap penilaian individu yang subjektif, dipengaruhi alam bawah sadar dan tidak diketahui secara khusus penyebabnya.

\subsection{Tahap Evaluasi}

Pada tinjauan teoritis evaluasi yang diharapkan adalah :

a. Membina hubungan saling percaya

b. Mengenali dan mengekspresikan emosinya 
c. Memodifikasi pola kognitif yang negative

d. Berpartisipasi dalam pengambilan keputusan yang berkenaan dengan perawatannya sendiri.

e. Termotivasi untuk aktif mencapai tujuan yang realistis. 


\section{BAB 5 \\ PENUTUP}

\subsection{Kesimpulan}

Berdasarkan uraian pada pembahasan diatas, maka penulis dapat disimpulkan bahwa:

1. Pengkajian dilakukan secara langsung pada klien dan juga dengan menjadikan status klien sebagai sumber informasi yang dapat mendukung data-data pengkajian. Selama proses pengkajian, perawat mengunakan komunikasi terapeutik serta membina hubungan saling percaya antara perawat-klien. Pada kasus Kecemasan : Gagal Ginjal Kronis

2. Diagnosa keperawatan yang utama pada klien dengan Kecemasan: Gagal Ginjal Kronis .

3. Perencanaan dan implementasi keperawatan disesuaikan dengan strategi pertemuan pada pasien.

4. Evaluasi keperawatan yang dilakukan menggunakan metode subyektif, obyektif, assessment dan planing.

\subsection{Saran}

1. Untuk institusi pendidikan

Diharapkan lebih meningkatkan pelayanan pendidikan yang lebih tinggi dan menghasilkan tenaga kesehatan yang profesional berwawasan global

\section{Untuk keluarga}

Diharapkan agar individu dan keluarga bisa mengerti tentang penyakit gagal ginjal kronis, dan meningkatkan perilaku hidup sehat dengan tujuan meningkatkan kualitas hidup. 


\section{DAFTAR PUSTAKA}

1. Avelina, Y., \& Natalia, I. Y. (2021). Hubungan Tingkat Kecemasan Dengan Kualitas Hidup Pasien Hipertensi Yang Sedang Menjalani Pengobatan Hipertensi Di Desa Lenandareta Wilayah Kerja Puskesmas Paga. Jurnal Keperawatan dan Kesehatan Masyarakat, 7(1).

2. Febrianti, D., Hamid, A. Y. S., \& Wardani, I. Y. (2015). Gambaran Asuhan Keperawatan Pada Klien Hipertensi Dengan Ansietas Menggunakan Pendekatan Uncertainty in Illness Dan Comfort Theory. Jurnal Ilmu Kesehatan, 7(2), 113-118.

3. Hulu, E. K., \& Pardede, J. A. (2016). Dukungan Keluarga Dengan Tingkat Kecemasan Pasien Pre Operatif Di Rumah Sakit Sari Mutiara Medan. Jurnal Keperawatan, 2(1), 12.

4. Kholidatin, Y. (2017). Hubungan Kecemasan Dengan Kualitas Tidur Pada Pasien Hipertensi Di Puskesmas Jati Kabupaten Kudus (Doctoral dissertation, Universitas Muhammadiyah Semarang).

5. Kuswaningsih, K., Jasmawati, J., \& Nulhakim, L. (2020). Pengaruh Teknik Relaksasi Nafas Dalam Terhadap Kecemasan pada Ibu Hamil dengan Hipertensi di Puskesmas Prangat Kabupaten Kutai Kartanegara.

6. Laka, O. K., Widodo, D., \& Rahayu, W. (2018). Hubungan Hipertensi dengan Tingkat Kecemasan pada Lansia di Posyandu Lansia Desa Banjarejo Kecamatan Ngantang Malang. Nursing News: Jurnal Ilmiah Keperawatan, 3(1).

7. Lestari, A. (2018). Pengaruh Terapi Psikoedukasi Keluarga Terhadap Pengetahuan Dan Tingkat Ansietas Keluarga Dalam Mera Wat Anggota Keluarga Yang Mengalami Tuberculosis Paru Di Kota Bandar Lampung. Jurnal Ilmiah Kesehatan, 1(1). https://doi.org/10.35952/jik.v1i1.105

8. Liska Yanti Angkat. (2017). Asuhan Keperawatan pada Ny. E dengan Prioritas Masalah Kebutuhan Aman dan Nyaman:Ansietas di Kelurahan Sari Rejo Kecamatan Medan Polonia. Karya Tulis Ilmiah

9. Lumi, F., Terok, M., \& Budiman, F. (2018). Hubungan Derajat Penyakit Hipertensi Dengan Tingkat Kecemasan Pada Kelompok Lanjut Usia Di Wilayah Kerja Puskesmas Kahakitang Kecamatan Tatoareng. Media Kesehatan Politeknik Kesehatan Makassar, 13(2), 59-68. 
10. Marbun, A., Pardede, J. A., \& Perkasa, S. I. (2019). Efektivitas Terapi Hipnotis Lima Jari terhadap Kecemasan Ibu Pre Partum di Klinik Chelsea Husada Tanjung Beringin Kabupaten Serdang Bedagai. Jurnal Keperawatan Priority, 2(2), 92-99. https://doi.org/10.34012/jukep.v2i2.568

11. Napitupulu, I. I. (2020). Gambaran Tingkat Kecemasan Berdasarkan Karakteristik Pada Lansia Yang Menderita Hipertensi Di Puskesmas Pancur Batu Tahun 2019.

12. Ndapaole, A. H. (2020). Pengaruh Pendidikan Kesehatan dengan Media Booklet terhadap Tingkat Kecemasan pada Penderita Hipertensi di Puskesmas Oepoi-wilayah Kerja Kota Kupang. CHMK Nursing Scientific Journal, 4(1), 162-170.

13. Pardede, J. A., Hulu, D. E. S. P., \& Sirait, A. (2021). Tingkat Kecemasan Menurun Setelah Diberikan Terapi Hipnotis Lima Jari pada Pasien Preoperatif. Jurnal Keperawatan, 13(1), 265-272. https://orcid.org/0000$\underline{0003-0114-4180}$

14. Pardede, J. A., Keliat, B. A., Damanik, R. K., \& Gulo, A. R. B. (2020). Optimalization of Coping Nurses to Overcoming Anxiety in the Pandemic of Covid-19 in Era New Normal. Jurnal Peduli Masyarakat, 2(3), 105112.https://dx.doi.org/10.31000/jkft.v4i2.2504

15. Pardede, J., Simanjuntak, G. V., \& Manalu, N. (2020). Effectiveness of deep breath relaxation and lavender aromatherapy against preoperative patient anxiety. Diversity and Equality in Health and Care, 17(4), 168-173. doi: 10.36648/206 9-5471.17.4.209

16. Pardede, J. A., \& Simangunsong, M. M. (2020). Family Support With The Level of Preschool Children Anxiety in the Intravenous Installation. Jurnal Keperawatan Jiwa (JKJ): Persatuan Perawat Nasional Indonesia, 8(3), 223234.

17. Pardede, J. A. (2020). Standar Asuhan Keperawatan Jiwa Dengan Masalah Kecemasan.

18. Pardede, J. A., \& Tarigan, I. (2020). The Anxiety Level of Mother Presectio Caesar with Benson's Relaxation Therapy. JENDELA NURSING JOURNAL (JNJ), 4(1), 20-28. https://doi.org/10.31983/inj.v4i1.5801

19. Pramana, K. D., Okatiranti, O., \& Ningrum, T. P. (2016). Hubungan Tingkat Kecemasan Dengan Kejadian Hipertensi Di Panti Sosial Tresna Werdha Senjarawi Bandung. Jurnal Keperawatan BSI, 4(2). 
20. Puspita, T., Ramadan, H., Budhiaji, P., \& Sulhan, M. H. (2019). Hubungan tingkat kecemasan dengan kualitas tidur pada lansia penderita hipertensi. Jurnal Keperawatan'Aisyiyah, 6(2), 53-58.

21. Rini, R. A. P. (2020). Pengaruh Kombinasi Aromaterapi Lavender dan Hand Massage Terhadap Perubahan Kecemasan, Tekanan Darah dan Kortisol pada Pasien Hipertensi (Doctoral dissertation, UNIVERSITAS AIRLANGGA).

22. Setyawan, A. B. (2017). Hubungan antara Tingkat Stres dan Kecemasan dengan Kejadian Hipertensi pada Lansia di Klinik Islamic Center Samarinda. Jurnal Ilmu Kesehatan, 5(1), 67-75.

23. Simanjuntak, G. V., Pardede, J. A., Sinaga, J., \& Simamora, M. (2021). Mengelola Stres di Masa Pandemi Covid-19 Dengan Hipnotis Lima Jari. Journal of Community Engagement in Health, 4(1), 54-57.

24. Stuart. Gail. W, Keliat. Budi. Anna,\& Pasaribu. Jesika. (2016). Keperawatan kesehal 11 tan jiwa: Indonesia : Elsever

25. Wahyuni, Sri Teguh Indah. (2018). Asuhan Keperawatan Jiwa dengan Masalah Psikososial: Ansietas Pada penderita PPOK. D3 Thesis. Universitas Airlangga. Surabaya. http://repository.unair.ac.id/id/eprint/75302

26. Yuwono, G. A., Ridwan, M., \& Hanafi, M. (2018). Pengaruh Pendidikan Kesehatan Tentang Hipertensi Terhadap Tingkat Kecemasan Pada Penderita Hipertensi Di Kabupaten Magelang. Jurnal Keperawatan Soedirman, 12(1), 55-66.

27. Zahara, F. (2019). Hubungan Antara Kecemasan Dengan Tekanan Darah Pada Penderita Hipertensi Di Rsu Pku Muhammadiyah Yogyakarta. Jurnal Psikologi Kognisi, 2(1), 42-53. 